\title{
The Threat of Forest and Vegetation Fires and the Possibilities of Intervention in Hungary
}

\author{
László BODNÁR, ${ }^{1}$ Péter PÁNTYA ${ }^{2}$
}

\begin{abstract}
Forest fires are natural disasters that endanger human life and material goods, which in many cases may pose a major challenge to the defence sector. Global climate change has been accepted as a fact in the professional literature from all areas of science. The increasing frequency of extreme weather events is a corollary to climate change. Sustained periods of droughts are becoming more common and in some cases, geographically more extended over Europe. In these dry and rainless periods, typically to that area, the vegetation is drier, thus giving rise to the ignition of the vegetation. An important role of this paper is to analyse and study the relevant domestic literature, as well as the personal consultations with the various experts. The results of the paper show that Hungary can be identified as a threat to forest fire and the possibilities of the intervention are set out. In addition, we can find out which are the organisations and technical tools that help us in such an intervention.
\end{abstract}

Keywords: forest fire, vegetation fire, forest fire statistics, tactics of the intervention, technical tools

\section{Introduction}

Due to the geographic location and to the climate of the country, Hungary is not among the most vulnerable countries of the risk of forest fires. Even so, the number of forest and vegetation fires are increasing. One of the reasons for this is climate change. Thousands of forest and vegetation fires occur every year. Every year, the number of vegetation fires exceeds the number of 9,000. It has been stated in many Hungarian studies on this issue that huge costs have to be paid during a forest fire, which shows why it is extremely important to examine the subject. [1] [2] [3] [4] Due to the forest and vegetation fires in Hungary, two highly flammable periods can be distinguished. Fires in the first group occur in spring when the snow cover is melted and when the vegetation has not yet grown out, but in the previous year there is a greater amount of dried herbaceous vegetation or foliage in the area that can easily and quickly dry out. These thin parts of the plants can dry up very soon in rainless time. Therefore, they can easily catch fire. The second group includes fires from

Ph.D. student, National University of Public Service; email: bodnar.laszlo@uni-nke.hu; ORCID: 0000-00019196-8030

2 Assistant Professor, National University of Public Service; email: pantya.peter@uni-nke.hu; ORCID: 00000003-2732-2766 
the droughty summer time. During the summer period, due to the longer dry and warm weather conditions, the duff and the needle leaf layers can completely dry and easily blaze up, also primarily due to human negligence. Their occurrence is typical in June and in August. Based on the data collection of recent years, it can be stated that $70 \%$ of forest and vegetation fires occur during the two highly flammable periods. [5]

\section{Characteristics of Forest Fires in Hungary}

\section{Weather Conditions and the Forest Cover in Hungary}

To determine the threat of a country's forest fire, it is indispensable to examine weather and geographic factors. The Carpathian Basin is located in Central Europe, in the temperate zone. In the north-western part of Hungary, the wet continental climate is typical. In the south-eastern part there is dry continental climate. The country's climate is influenced by the western winds due to the oceanic effect and the Mediterranean effect from the south. The direction of the wind is northwest to the Tisza river, further from it to the east the wind is northeast. The country has a pool-type shape. The middle of the pool is the hottest and the driest. This poses the danger that droughty summers can develop. The weather varies rapidly, largely due to the flow of remote air pressure centres. Based on this, it is possible -because of the weather conditions of the country - that the vegetation can easily ignite. [6]

If we want to investigate Hungary's vulnerability of forest fires, we need to check the forest cover of the country.

Forest cover in Hungary in 2017

\begin{tabular}{|l|c|l|c|}
\hline \multicolumn{1}{|c|}{ County } & Forest cover (\%) & \multicolumn{1}{c|}{ County } & Forest cover (\%) \\
\hline BUDAPEST & 10.2 & TOLNA COUNTY & 17.8 \\
\hline PEST COUNTY & 25.8 & BORSOD-ABAÚJ-ZEMPLÉN COUNTY & 29.2 \\
\hline FEJÉR COUNTY & 12.4 & HEVES COUNTY & 24.3 \\
\hline KOMÁROM-ESZTERGOM COUNTY & 27.3 & NÓGRÁD COUNTY & 39.2 \\
\hline VESZPRÉM COUNTY & 30 & HAJDÚ-BIHAR COUNTY & 11.3 \\
\hline GYÖR-MOSON-SOPRON COUNTY & 19 & JÁSZ-NAGYKUN-SZOLNOK COUNTY & 5.9 \\
\hline VAS COUNTY & 28.2 & SZABOLCS-SZATMÁR-BEREG COUNTY & 21.3 \\
\hline ZALA COUNTY & 31.7 & BÁCS-KISKUN COUNTY & 20.8 \\
\hline BARANYA COUNTY & 25.2 & BÉKÉS COUNTY & 4.6 \\
\hline SOMOGY COUNTY & 29.7 & CSONGRÁD COUNTY & 8.9 \\
\hline
\end{tabular}

Figure 1. The forest cover in Hungary. [7]

In Figure 1, we can see the forest cover of the country. Overall, we can say that the forest areas are concentrated in Hungary. Due to geological and climatic conditions, extensive forests were developed in the hilly regions of North Hungary and Southern Transdanubia. According to the counties, the largest forest area is in the northern Borsod-Abaúj-Zemplén county. This is $29 \%$ of the country's forests. The forest areas are also significant in Somogy, Bács-Kiskun and Pest county. The degree of forestry varies greatly depending on the territorial characteristics. The least number of forests are in Central Hungary (Budapest, Pest county), but the forest cover is higher than the national average. Northern Hungary 
has the largest forested area, as most of its area is covered by hills. The Northern Great Plain region is the least afforested, where agricultural areas are more typical. The forests of the Transdanubia regions are relatively balanced. The proportion of the forest area in Nógrád is highest (nearly 40\%), but it is also significant in Veszprém, Zala, Somogy and Borsod-Abaúj-Zemplén. Békés county has the smallest forest cover, it is under 5\%. [7]

\section{The Fire Risk of Hungary}

Forest fire does not know any boundaries, therefore, forest fires cannot be separated from other vegetation fires burning in non-forest areas, because fires often spread not only in the forest area. In Hungary, due to the characteristic weather conditions and the composition of the vegetation, natural fires are not typical, and their proportion is below $1 \%$. It can be verified by statistical data that the vast majority of outdoor fires are a consequence of human negligence.

Indirectly, the effects of the climate change also appear in the number of outdoor fires and the size of the burned areas, which in the future will be even more challenging for Hungary's disaster management. Due to the increasing number of forest fires, the length of the high flammable periods also increase during the fire season. It is also important to take into account the increasing intensity of the forest fires, so firefighting will be more difficult.

The fire risk of a forest or other non-vegetated area is influenced by a number of parameters, which must be considered together. The risk of forest fire depends on the amount of combustible biomass in the area, on the terrain, on the weather conditions, on the microclimate and on the human activity. The fire risk classification of the forest areas indicates the static vulnerability of the given forest fragment. The forestry authority determines and keeps records of the fire risk classification of forests in a single data store. The forest fire risk classification takes into account the tree parameters used in forestry plant design descriptions. So, it expresses the amount of combustible biomass and its vulnerability, contained in that forest fragment. [8]

In case of all firefighting activity, it is very important to deal with safety intervention. Safety intervention is very important not only at a forest fire, but at radiological emergencies and in all general activities, as well. [9] [10]

\section{Statistics on Forest Fires in Hungary}

Besides the forest cover of the country it is very important to deal with the statistics on forest fires. In Figure 2 we can find the risk classification of forest fire in the counties of Hungary. In Hungary, we distinguish largely, middling and moderately vulnerable county categories of the risk of forest fires. As shown in Figure 2, a highly vulnerable county (dark) is Borsod-Abaúj-Zemplén and Bács-Kiskun county. 


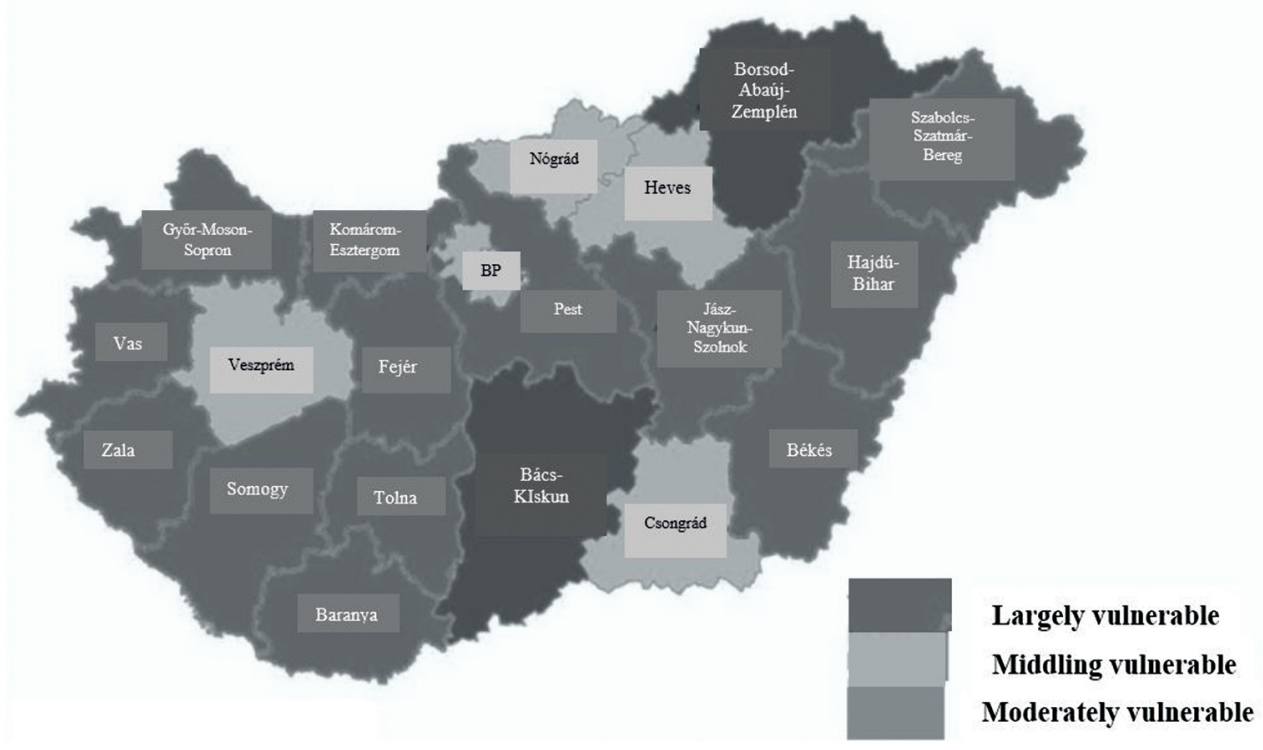

Figure 2. Vulnerability of the counties in Hungary. (Based on $[11]^{3}$ edited by the authors.)

The area of Bács-Kiskun county is composed of large forests and easily sunken juniper stocks. The most vulnerable stocks in the county include bog-spruce. In Borsod-AbaújZemplén county leafy forests are the most vulnerable stock. The county’s vulnerability is increased by the fact that there are many abandoned agricultural areas where firefighting is very difficult because of this biomass. In addition to these, there are other reasons such as sociological and economic problems. Similar problems are encountered in Nógrád county and Heves county, where only the smaller forest cover supports the fact that they these counties are not among the most vulnerable areas. Middling vulnerable counties (light color) are Budapest and Pest county, where mainly the agglomeration area of the capital is the most endangered. In the capital, the leafy stocks and the incoming people are the biggest threat. The towns of the Pilis Basin, which are located west of the capital, belong to this category. In these settlements pine trees are subject to the higher risk. Another problem is that these areas are among the favourite recreational areas of the Pilis Basin. Veszprém county is also a middling classified area, where the oaks and shrubs of the Balaton Uplands and the Keszthely Mountains are endangered. In this region we should mention the role of the recreational areas as well, like in Pest county. The danger of Csongrád county is caused by the large number of inhabitants living in the outskirts and by the structures of farmed settlements. Although the county's forest cover is small, the black pines are threatened by forest fire protection risks. [11]

After presenting the vulnerability of Hungary's forest stocks, it is worth noting that besides the fire risks arising from the biomass structure, human influence also has a great impact on the endangerment of forest stocks in individual parts of the country. In the highly

NÉBIH - National Food Chain Safety Office (NFCSO). 
flammable counties, primarily human negligence or intent (99\%) is the cause of the fire. Given that less than $1 \%$ of the forest and vegetation fires occur naturally, it can be established that fire risk forecasting can be more effective if this problem is also communicated to the citizens.

\begin{tabular}{|c|c|c|c|}
\hline \multicolumn{4}{|c|}{ Forest and vegetation fires in Hungary } \\
\hline \multirow{2}{*}{ Year } & \multirow{2}{*}{$\begin{array}{c}\text { All vegetation } \\
\text { fires }\end{array}$} & \multicolumn{2}{|c|}{ Forest fire } \\
\cline { 3 - 4 } & 6,691 & Number of Fires & Burned areas (ha) \\
\hline 2007 & 6,639 & 502 & 4,636 \\
\hline 2008 & 8,658 & 608 & 2,404 \\
\hline 2009 & 3,120 & 109 & 6,463 \\
\hline 2010 & 8,436 & 2,021 & 878 \\
\hline 2011 & 21,581 & 2,657 & 8,055 \\
\hline 2012 & 4,602 & 761 & 14,115 \\
\hline 2013 & 5,783 & 1,042 & 4,955 \\
\hline 2014 & 5,318 & 1,069 & 4,454 \\
\hline 2015 & 2,489 & 452 & 9730 \\
\hline 2016 & & \multicolumn{2}{c}{} \\
\hline
\end{tabular}

Figure 3. Statistic presentation of the forest and vegetation fires in Hungary. [12: 4]

The specific forest fire statistics are shown in Figure 3. The table shows the number of fires of all forest and vegetation in the past 10 years coupled with the size of burned areas. Based on the statistical data it can be stated that the number of fires is different every year. There are also high and low values. The number of fires that occurred in a given year is greatly influenced by the amount of precipitation in the early spring and summer months. Overall, according to the data of the past 10 years, the average size of the areas burned by vegetation fires is approximately 8,000 hectares. The average number of fires is about 1,000 hectares. The total area burned by forest fires is almost 5,000 hectares. According to other articles, at a large forest fire, we need to take into consideration enormous costs. [2] [13]

Overall, it can be stated that in Hungary-although this is not the most significant natural disaster - forest fires should be of utmost importance, as it gives half of the annual fleet of firefighters. We can see how many areas are destroyed by forest fires in a year, so we need to find some sort of solution to prevent this, not especially in the field of intervention but in fire prevention, as well. [14]

\section{Firefighting During Forest and Vegetation Fires}

Firefighting during forest and vegetation fires is a complex task. The intervening forces must pay attention to a lot of circumstances. For this reason, in Hungary, a Firefighting Order and a Technical Rescue Order are issued in order to help the intervening forces. [15] 
L. BODNÁR, P. PÁNTYA: The Threat of Forest and Vegetation Fires and the Possibilities...

\section{Detection}

One of the most important part of the intervention of a forest fire is detection. During detection it is important to deal with the following factors:

- it is important to obtain a map of the affected area, as soon as possible; it is also important to identify the boundaries of the vulnerable area and its vaccination, protection and parry tasks;

- if it cannot be detected due to field conditions or the extent of a fire, it is advisable to arrange for aerial reconnaissance;

- residential areas threatened by the fire must be determined;

- people's way of escape must be determined;

- the direction of the fire must be determined;

- $\quad$ water supply and the approach route must be determined;

- the direction and the speed of the wind must be determined;

- escape and escape routes must be determined.

During a large forest fire, it is important to strive to use aerial detection, because it is more effective than ground detection. [15]

\section{Intervention}

Intervention at a forest fire is a difficult activity. Attention should be paid to the following:

- the large-scale forest and vegetation fires require special equipment and tactics;

- if the size, complexity or duration of the fire justifies it, leadership should be organised;

- the members of the leadership should be experts.

In case of a large forest fire, the leader of the firefighters must create and separate firefighting sections. These sections are capable of performing individual and coordinated tasks for each firefighting within the territory. The section commander is at the head of the sections. This commander keeps contact with the other groups and sections.

In the event of an aerial firefighting, rigid wing and rotor units interfere separately from each other. Provision should be made for the supply of air units with vaccines. Aerial reconnaissance, vaccination, rescue with the simultaneous use of multiple aircraft flight control can only be performed by qualified earth stations. In addition, firefighting should be given increased attention in the burning area for high voltage lines.

At the post production activities, it is important to examine the burned area, in order to prevent the further burning of the stumps, trunks and the ground. Smouldering parts are also important - in the absence of water - they should be covered with soil and sand. After the fire, the leader of the firefighters contacts the forest manager for increased surveillance of the affected area. [15] 


\section{Intervening Forces}

In Hungary, the primary intervening forces are the fire departments. These can be organisations that make various firefighting and rescue tasks. These departments are the following in Hungary:

- professional fire department: created for firefighting, technical rescue and fire prevention tasks; they have a separate operating area;

- disaster management post: the professional fire department set it up to perform firefighting, technical rescue and fire prevention tasks;

- municipal fire department: created for firefighting and technical rescue tasks; they are voluntary fire departments with operational districts;

- industrial fire department: created for firefighting and technical rescue tasks; this is a fire service without an independent operating area, created by an economic organisation;

- voluntary fire department: an association which can be involved or can participate in fire prevention and rescue task activities;

- intervener voluntary fire department: the activity of it is based on an agreement with a professional disaster management agency; they are involved in firefighting and rescue activities. [16]

\section{Disaster Management Operation Services}

Disaster Management Operation Services operate on the county level, and are 24/48 hours on a standby service. They can lead complex and higher risk interventions also during forest fires. At an intervention area, they supervise and control the intervention of the intervening staffs. They make effective and safety interventions during a disaster. [17]

Overall, it can be seen that a large number of disaster relief units are intervening during a forest fire in Hungary. However, these units do not properly cover all the territory of the country. The current dislocation of professional fire services does not allow every territory to be available within 25 minutes, therefore creating disaster guards is planned to improve the dislocation. In addition, voluntary fire departments can make firefighting missions as a municipal fire service within their own landing area. The operating site of the professional fire services is the area where a municipal fire service voluntarily assumes the primary intervention activity. They are supervised and controlled by the professional fire services. Firefighting is also assisted by voluntary firefighters who take part in professional activities, who are able to support the professional fire services from the early stages of intervention. Currently there are 315 cooperation agreements with voluntary fire departments in Hungary. Their work can also help to solve the problem of dislocation. 


\section{Special Aerial Equipment}

\section{Outside Tanks}

In the $19^{\text {th }}$ century people tried to perform firefighting tasks from the air, but these ideas were somewhat primitive. These were machines with a single engine, and the firefighters spilled the water from a bin. The idea was good, but was not efficient. The authorities in California saw imagination in it, so they began to innovate the original idea. Before the Second World War, they built a double-decker aeroplane and fixed tanks to it. After the take-off, they dumped the water from these tanks. [18] After many attempts and experiences they improved the outside tank technology. Today we can find different bins and buckets that are especially fabricated for the aim of aerial firefighting. These bins and buckets proved very effective. [19]

According to the German literature there are 4 types of hanged burdens. [20]

Table 1. Types of the hanged burdens.

(Based on [20] [21] edited by the authors.)

\begin{tabular}{|l|l|}
\hline Load type 1 & "Short line" (length of the device $<20 \mathrm{~m}$ ) \\
\hline Load type 2 & "Long line” (length of the device $>20 \mathrm{~m}$ ) \\
\hline Load type 3 & "Logging” (Transport of unsorted and disordered logs) \\
\hline Load type 4 & The burden is required to be kept in a certain position on the helicopter. \\
\hline
\end{tabular}

\section{Bambi Bucket Models}

During aerial firefighting, the firefighters used Bambi Buckets most commonly as a hanged burden. [1] These buckets are made in different sizes from the 270 litres to more than 9,000 litres; they not only have different sizes; their types also differ. The most commonly used types are the Bambi Bucket Modell 1012, the Bambi Bucket 2000 and the Bambi Bucket Modell 1518. [19] [21]
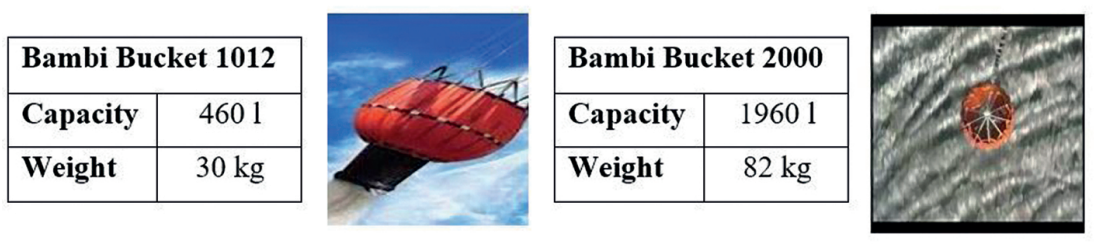

\begin{tabular}{|l|c|}
\hline \multicolumn{2}{|l|}{ Bambi Bucket 1518 } \\
\hline Capacity & 6801 \\
\hline Weight & $40 \mathrm{~kg}$ \\
\hline
\end{tabular}

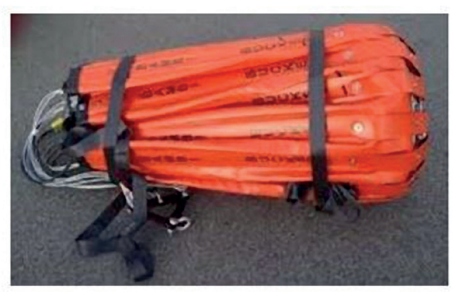

Figure 4. A collection of Bambi Bucket family. [21] 
The essence of the Bambi Bucket is, that the firemen fix a tank with a rope to the bottom of the helicopter. The helicopter makes the bailing above the water, after that it arrives to the burning zone and dumps the water through an opening of the Bambi Bucket. The advantage of the Bambi Bucket is that the helicopter does not need any necessary changes to use the vehicle for firefighting aims. We just need to connect the burden to the helicopter and the helicopter is ready to do the firefighting. So helicopters made for another aim can be suitable for firefighting, as well. There are two different methods to fill the tanks. On the one hand, the helicopter can be filled from a tank with a pump at a temporary nearby airport. On the other hand, the helicopter can be filled from a nearby lake. In Hungary, Mi-2 and Mi-8 helicopters are used for firefighting aims. These helicopters need minimum 1.5 metres deep water to fill up. Operating a Bambi Bucket bin, we can use the Sackfoam family. It can be controlled from the board, and it can inject a foam compound (0.5-1\%) to the bin. To make it more efficient, we can use FireSock mixed bags, which help the solution to mix more efficiency with the air. This equipment helps in the foaming, and exerts a more efficient extinguishing effect. [22]

We can use this method in case of any forest fire; still we have to mention the difficulties, as well. Because of the hanged burden, it is difficult to manoeuvre the helicopter. Furthermore, it is hard to collect enough water to fill the tanks, and the depth of the water is also very important. In Hungary, there are many water sources (ponds, aquifers), because of the pool-type of the country, but in several countries it is a big problem (for example Spain and the South Slavic region).

\section{Conclusion}

In this article, we introduced the threat of forest and vegetation fires, the statistics of the forest fires, the intervening forces and some special tools in Hungary. As a result of this article, it is possible to characterise the types of the Hungarian forest and vegetation fires, the fire risk and the most vulnerable forest areas in the country. We also presented how to make an intervention during a wildfire, what are the causes and what kind of special equipment can be used. The most important data and information of this article provides an opportunity for the more effective firefighting and fire prevention of the Hungarian disaster management. The implementation of effective firefighting and fire prevention has a great importance in Hungary, it also has its special methods and practices, such as the forest conversion method, the firebreaks and the water springs established in the forests. They will be presented in another article in the future.

\section{References}

[1] KÓS Gy. - KOMJÁTHY L.: Erdőtüzek helikopteres oltása. Repüléstudományi Közlemények, 242 (2012), 471-482.

[2] BODNÁR L.: Logistic problems of fighting forest fires based on case studies from Hungary. In. GRZEŚKOWIAK, Ł. W. - KOWALEWSKI, P. - RATAJCZAK, I. - CIORGA, B., FANFAROVÁ, A., GAŠPERCOVÁ, S., MAKOVICKÁ OSVALDOVÁ, L. - 
L. BODNÁR, P. PÁNTYA: The Threat of Forest and Vegetation Fires and the Possibilities...

RESTÁS Á. - PANÁKOVÁ, J. eds.: Proceedings of the 8th International Scientific Conference Wood and Fire Safety. Zilina, EDIS Zilina University Publishers, 23-32.

[3] RESTÁS Á.: The Examination of the Economical Effectiveness of Forest Fire Suppression by Using Theoretical Fire Spread Models. AARMS, 151 (2016), 85-92.

[4] HALASSY G. - RESTÁS Á.: Some Economic Aspect of Disaster Management Especially Focusing on Firefighting. In. $11^{\text {th }}$ International Conference on "Environmental Legislation, Safety Engineering and Disaster Management” Elsedima: Building Disaster Resilience in a Changing Word (Book of abstracts). Cluj, Babes-Bolyai University, Faculty of Environmental Science and Engineering. 81-81

[5] DEBRECENI P. - BODNÁR L. - PELLÉRDI R.: Az erdőtűz kockázatának csökkentési lehetőségei Magyarországon. Védelem Tudomány, 22 (2017), 1-11.

[6] Magyarország éghajlata és vízrajza. (s.a.) http://tudasbazis.sulinet.hu/hu/ termeszettudomanyok/foldrajz/regionalis-foldrajz/magyarorszag-foldrajza/magyarorszageghajlata-es-vizrajza (Downloaded: 08.11.2018)

[7] NÉBIH: Magyarország erdeivel kapcsolatos adatok. Budapest, Nemzeti Élelmiszerláncbiztonsági Hivatal, (s.a.) https://portal.nebih.gov.hu/-/magyarorszag-erdeivel-kapcsolatosadatok (Downloaded: 08.11.2018)

[8] DEBRECENI P. - NAGY D.: Erdőterületek erdőtüz-veszélyességi besorolása. Budapest, NÉBIH Erdészeti Igazgatóság, 2010.

[9] FINTA V. - RÁCZ S.: Firefighter Intervention in Radiological Emergencies. In. SAVIĆ, B. - MILANKO, V. - LABAN, M. - MRAČKOVA, E. - RESTÁS Á. - PETROVIĆ, B. eds.: Међународна Научна Конференција Безбедносни Инжењеринг. [5 ${ }^{\text {th }}$ International Scientific Conference on Safety Engineering and $15^{\text {th }}$ International Conference on Fire and Explosion Protection. Book of Proceedings.] Novi Sad, University of Novi Sad, Faculty of Technical Sciences, 2016. 180-186.

[10] PÁNTYA P.: Safety Issues of Firefighting Interventions. In. BALOG K. - MARTINKA, J. eds.: Recenzovaný zborník pôvodných vedeckých prác z III. ročníka medzinárodnej vedeckej konferencie. [Advances in Fire and Safety Engineering.] Trnava, AlumniPress, 2014. 215-220.

[11] NÉBIH: Tájékoztató az erdőtúzvédelmi tervek készítéséről. Budapest, Nemzeti Élelmiszerlánc-biztonsági Hivatal, (s.a.) http://portal.nebih.gov.hu/-/tajekoztato-azerdotuzvedelmi-tervek-kesziteserol (Downloaded: 01.05.2017)

[12] DEBRECENI P.: A 2016. évi vegetációtűz szezon bemutatása. http://erdotuz.hu/wp-content/ uploads/2017/01/Erd\%C5\%91t\%C3\%BCzek-Magyarorsz\%C3\%A1gon2016-ban.pdf (Downloaded: 08.08.2017)

[13] RESTÁS Á.: Measuring the efficiency by mixing the costs and the effectiveness of extinguishing materials and aerial firefighting. In. BLINOVÁ, L. BARTOŠOVÁ, A. - SIROTIAK, M. - RESTÁS Á.: Management of Environment. Bratislava, Slovak Society of Environmental Technology, 2017. 118-124.

[14] NAGY D.: Az erdőtüzek megelőzési és oltástechnológiai lehetőségeinek vizsgálata. (PhDértekezés). Sopron, Nyugat-magyarországi Egyetem, 2008.

[15] 6/2016. (VI. 24.) BM OKF utasítás a Tüzoltás-taktikai Szabályzat és a Müszaki Mentési Szabályzat kiadásáról.

[16] Tüzoltás, műszaki mentés. Budapest, BM Országos Katasztrófavédelmi Főigazgatóság, (s.a.) www.katasztrofavedelem.hu/index2.php?pageid=tuzoltas_index (Downloaded: 10.01.2018) 
L. BODNÁR, P. PÁNTYA: The Threat of Forest and Vegetation Fires and the Possibilities...

[17] Katasztrófavédelmi múveleti szolgálat. Szent Flórián Önkéntes Túzoltó Portál. (s.a.) www. szentflorian.hu/?pageid=katved_kmsz\&menuid=katved (Downloaded: 15.01.2018)

[18] CIFKA M.: Tüzoltás a levegőből. sg.hu, 31.08.2005. https://sg.hu/cikkek/39094/tuzoltas-alevegobol (Downloaded: 10.01.2018)

[19] BODNÁR L.: The efficiency of the aerial firefighting in Hungary using outside tank technology. In. SAVIĆ, B. - MILANKO, V. - LABAN, M. - MRAČKOVA, E. - RESTÁS Á. - PETROVIĆ, B. eds.: Међународна Научна Конференција Безбедносни Инжењеринг. [5th International Scientific Conference on Safety Engineering and 15th International Conference on Fire and Explosion Protection. Book of Proceedings.] Novi Sad, University of Novi Sad, Faculty of Technical Sciences, 2016. 187-194.

[20] Bayerische Staatsregierung - Richtlinie für die Zusammenarbeit von Feuerwehr und Luftfahrzeugbetreibern in Bayern. Stand: 27 August 2013.

[21] Staatliche Feuerwehrschule Würzburg - Lehrunterlage für den Flughelfer-Lehrgang. Stand: July 2014.

[22] RESTÁS Á.: Az erdőtüzek légi felderítésének és oltásának kutatás-fejlesztése. (PhDértekezés). Budapest, Zrínyi Miklós Nemzetvédelmi Egyetem, 2008. 